\title{
ПОЄДНАННЯ ОСВІТНЬОЇ ТА ТРУДОВОЇ ДІЯЛЬНОСТІ ЯК РЕАЛІЗАЦІЯ ПРАГНЕННЯ СТУДЕНТСЬКОЇ МОЛОДІ ДО ЕКОНОМІЧНОЇ СЕПАРАЦЇ̈
}

\author{
Наталія Корчакова \\ доктор психологічних наук, доцент, \\ професор кафедри вікової та педагогічної психології \\ Рівненський державний гуманітарний університет \\ 33000, Україна, м. Рівне, вул. С. Бандери, 12 \\ nataliia.korchakova@rshu.edu.ua, http://orcid.org/0000-0003-1164-3370
}

\begin{abstract}
Анотація
Сучасна тенденція студентства поєднувати навчання з трудовою діяльністю може мати як позитивні, так і негативні наслідки: зрілість і економічна автономія, з одного боку, та втрата системності й послідовності набуття професійних знань - 3 іншого. Це може призвести до зниження якості професійних компетенцій та, зрештою, до девальвації сутності вищої освіти загалом. Метою статті $є$ аналіз мотиваційного аспекту намірів студентів здобути економічну незалежність від батьківської сім'ї шляхом поєднання вищої освіти з роботою.

В дослідженні взяли участь 80 студентів третього курсу (М=19,7 року). Отримані результати підтвердили припущення, що мотиваційною основою для прийняття рішення про працевлаштування була не необхідність вирішення фінансових труднощів, а прагнення досягти особистої автономії й незалежності. 3'ясовано структуру потребової сфери студентів і амбівалентний характер процесів сепарації, оскільки, всупереч своїм прагненням, студенти продовжують покладатися на фінансову підтримку батьків. В поєднанні 3 високими показниками рівня суб'єктивного економічного благополуччя це підтвердило припущення про домінуючу роль внутрішніх психологічних спонук, а не об'єктивної економічної ситуації в процесі прийняття рішення про працевлаштування. Встановлено, що студенти чітко розуміють негативний вплив такого поєднання на якість формування їх професійних навичок. Проведений факторний аналіз мотивації працевлаштування студентів дозволив виділити 3 основні фактори: «Незалежності» (утворений мотивами самоствердження, усвідомлення власної дорослості, прагнення до економічної незалежності й матеріальних труднощів сім'ї); «Трудового досвіду» (мотиви заробітку, набуття професійного досвіду, навичок); «Зовнішньої стимуляції» (мотиви моди і зразки поведінки однолітків).
\end{abstract}

Ключові слова: психологічна сепарація, економічна сепарація, суб'єктивне економічне благополуччя, монетарні установки, студентство.

\section{Вступ}

Одним із серйозних викликів, з яким зустрілася сучасна вища школа, є підвищення інтересу молоді до поєднання навчання 3 трудовою діяльністю. В минулі роки подібні прагнення простежувалися переважно у студентів старших курсів. На сучасному етапі таке поєднання стає елементом життєдіяльності більшості здобувачів вищої освіти, включаючи навіть тих, хто лише розпочинає професійну підготовку чи навчається на молодших курсах. Негативним наслідком цих тенденцій є втрата системності та послідовності у засвоєнні студентами професійних знань, відсутність у них можливостей виконувати навчальні 
завдання у повному обсязі. Як наслідок, обезлюднення аудиторій веде до зниження якості професійної підготовки майбутніх фахівців, знецінення сутності навчання у виші, зниження професійних компетенцій випускників. Зазначимо, що у цьому випадку мова не йде про реалізацію принципу дуальної освіти, оскільки більшість працевлаштувань студентів не пов'язані з напрямком їх професійної підготовки у закладі вищої освіти, а отже, не забезпечують поглиблення їх професійних знань чи набуття ними відповідних умінь.

Що ж спонукає молодь до вибору означеної стратегії? Як зіставляються ситуативні та диспозиційні чинники, що обумовлюють цей процес? Спираючись на ідеї, декларовані молоддю, можна припустити, що центральну функцію у цьому процесі відіграє низький рівень матеріального та фінансового благополуччя родин, у яких вони зростають. Все ж, за нашим розумінням, висновки про сутність цих процесів можна зробити лише на основі вивчення їх психологічної природи. Попередньо можна припустити, що звернення молоді до більш раннього працевлаштування пов'язане із змінами, що відбулися у мотиваційноціннісній сфері молодого покоління та особливостями розвитку у них сепараційних процесів.

Як відомо, сепарація від батьків (від лат. separates - «окремий») розглядається у психологічній науці як стратегія відокремлення молодої людини від батьківської сім'ї, здобуття нею незалежності та особистісної свободи у прийнятті життєво важливих рішень. Відзначено, що цей інтрапсихічний процес відбувається на емоційному, функціональному, атитюдному і конфліктологічному рівнях (Hoffman, 1984). Він забезпечує перебудову всієї системи дитячо-батьківських стосунків (Дзукаева, 2016; Литвинова, 2020) і набуття молодою людиною особистісної автономії (Петренко \& Сысоева, 2016).

Психологічні аспекти сепарації студентської молоді від батьківських родин і розвиток їх незалежності висвітлено в українській науці (Карамушка \& Ходакевич, 2017; Ковальчук, 2013; Літвінова, 2018; Широка, 2013) та в працях науковців країн ближнього зарубіжжя (Дитюк, 2015; Литвинова, 2020; Дзукаева \& Садовникова, 2014; Петренко \& Сысоева, 2016).

Спроба прослідкувати особливості процесів сепарації-індивідуації впродовж навчання у виші подана в лонгітюдному дослідженні (Aslan \& Gelbal, 2016). За висновками авторів, ці процеси унормовуються, позбуваються зайвої конфліктності та набувають позитивного змісту ближче до завершення навчання в університеті. Подібні результати були отримані при вивченні питань вікового генезу сепарації. Автори відзначили, що, поєднуючи у собі періоди високої й низької активності, зазначене явище досягає піку наприкінці навчання у виші, збігаючись із періодом нормативної кризи переходу від юності до ранньої дорослості (Петренко \& Сысоева, 2016).

Важливим напрямком вивчення особливостей набуття молоддю особистісної автономії та сепарації від батьківської сім’ї є дослідження гендерних особливостей цього процесу. В праці Г. Литвинової аналізується гендерна специфіка детермінуючого впливу психологічної сепарації на розвиток ціннісно-смислових та операційних характеристик цілепокладання в студентському віці. Зазначено, що взаємозв'язок сепарації i цілепокладання у дівчат і хлопців відрізняється великою варіативністю та суперечливістю (Литвинова, 2020). Амбівалентний характер процесів пошуку автономії підкреслили й інші вчені (Geuzaine, Debry \& Liesens, 2000), які, аналізуючи гендерні аспекти сепарації молоді, визначили, що, на відміну від хлопців, дівчата більше потребують емоційної підтримки 3 боку батьків (особливо матері), водночас, декларуючи стійке прагнення до особистої автономії. Це узгоджується також із результатами дослідження В. Дзукаєвої, яка відзначила, 
що когнітивна і поведінкова сепарація в юнацькому віці виявляються значно інтенсивніше, випереджаючи в своєму розвитку афективну складову (Дзукаева, 2016).

Особливо актуальним, в сенсі відповідності меті нашого дослідження, є праця Л. Карамушки й О. Ходакевич, які вивчаючи ставлення студентів до грошей, встановили, що процеси сепарації залежать від дії зовнішніх і внутрішніх чинників, важливу роль серед яких має загальножиттєва спрямованість особистості - зорієнтованість на загальну активність, соціальний статус, мотивацію заробітку грошей. Констатовано, що підвищення мотивації щодо соціального статусу корелює зі зростанням позитивного ставлення до грошей (Карамушка \& Ходакевич, 2017).

Саме здатність молодої людини не лише жити самостійно, а й планувати та реалізовувати свої основні життєві програми, досягти фінансової незалежності є показником iï особистісної зрілості, незалежності та автономності. Реалізація цієї мети у період навчання у виші є досить проблематичною, у зв'язку з певною різноспрямованістю цільових установок у навчальній і трудовій діяльності. Якщо в першому випадку увага студента зосереджена на набутті знань та первинних професійних умінь, то у другому - на отриманні фінансової винагороди за докладені зусилля.

Метою статті $є$ аналіз психологічних передумов прагнення студентської молоді до здобуття економічної незалежності від батьківської сім’ї, шляхом поєднання навчання у вищому навчальному закладі з трудовою діяльністю. Для реалізації мети було визначено такі завдання: 1) визначити структуру взаємозв'язків основних мотивів пошуку роботи під час навчання; 2) проаналізувати монетарні атитюди сучасної молоді та їх зв'язок зі ставленням до працевлаштування; 3) дослідити взаємозв'язок суб' єктивного економічного благополуччя та установок студентів щодо поєднання навчання та роботи.

\section{Методи дослідження}

Дослідження проводилося на базі Рівненського державного гуманітарного університету. В ньому взяли участь студенти 3 курсу. Загальний обсяг вибірки - 80 осіб. Віковий діапазон 19,2-19,9 р. М=19,7 р.

В дослідженні використовувалися такі методики: «Опитувальник вимірювання монетарних атитюдів» (авт. Klontz, et.al, адап. Баязитова \& Лапшова), «Іерархія потреб» (модиф. Акіндінової); «Опитувальник суб’єктивного економічного благополуччя» (авт. Хащенко); анкета «Ваше ставлення до дуальної освіти». Питання анкети спрямовані на 3'ясування суб'єктивного оцінювання студентами свого економічного благополуччя, їхнє ставлення до поєднання навчання і роботи, наявності досвіду трудової діяльності, емоційної реакції батьків на працевлаштування. При обробці результатів використовували методи математичної статистики: факторний та кореляційний аналіз, критерій Крускала-Уолеса.

\section{Результати та дискусії}

Започатковуючи аналіз емпіричних даних, передусім, зупинимося на питанні наявного рівня економічної незалежності респондентів від батьківської сім'ї, оскільки цей показник, за нашим розумінням, $€$ одним із центральних критеріальних показників емоційного благополуччя особистості у цей віковий період. Як показало опитування, лише п'ята частина студентів $(22,5 \%)$ визнала повну економічну залежність від батьківської родини. (Зазначимо, що для визначення показників залежності ми використали п'ятирівневу шкалу Потапової та Маленової (2013), яка дозволяє диференціювати суб'єктивну міру 
економічних зв'язків молоді у діапазоні «залежу від батьків - надаю їм матеріальну допомогу»). Решта учасників опитування $(87,7 \%)$ відзначили наявність певних рівнів фінансової свободи та унезалежнення. Найбільші підгрупи у вибірці утворили респонденти, що обрали позицію «маю невеликий заробіток, але, загалом, залежу від батьків» (40\%) та позицію «можу забезпечити свої первинні потреби, але на великі покупки беру чи позичаю гроші у батьків» (27,5\%). Близько десяти відсотків респондентів $(9,8 \%)$ декларують позиції повної економічної незалежність від родини чи навіть фінансової їі підтримки.

Оскільки нас цікавило питання наявності у студентів прагнень до поєднання навчання 3 трудовою діяльністю, то ми проаналізували характер апробованих ними трудових взаємин. Майже половина опитаних (45\%) вказали на те, що їхні трудові стосунки мають характер періодичних. Ще третина учасників дослідження (30\%) декларують ідею постійного працевлаштування, при цьому кожен шостий учасник позначає трудові відносини із повним робочим навантаженням. Оскільки опитування проводилося по завершенню п'ятого семестру (середина третього курсу), то можна прогнозувати, що така зайнятість, не може не позначитися на якості навчальної діяльності студентів. До того ж, необхідно враховувати, що традиційно, навчальні плани третього курсу мають один із найвищих рівнів професійної спрямованості. Саме тут здійснюється викладання навчальних дисциплін, що забезпечують основи професійної підготовки майбутніх фахівців. Не сприяє формуванню професійних компетенцій також і те, що напрямок працевлаштування багатьох студентів (82\%), не пов'язаний із їхньою майбутньою професією. Отже, мова йде не про набуття студентами професійних знань та умінь, а про реалізацію програми заробітку грошей.

Чи помічають самі студенти ті небезпеки, які зумовлені цим типом конвергенції трудової й навчальної діяльності? Отримані результати засвідчують, що на рівні когнітивних міркувань, таке розуміння у більшості з них присутнє. Зокрема, оцінюючи рівень зниження якості навчання за десятибальною шкалою, лише п'ята частина студентів (19,5\%) вказали на низький рівень (у межах 1-3 балів) можливих проблем. Більшість представників працюючої молоді (80,5\%) вважає, що якість їхнього навчання знизиться в межах середнього (4-6 балів) чи високого рівнів (7-10 балів). Це становить відповідно 39\% та 41,5\% опитаних. При цьому студенти усвідомлюють, що проблеми виникатимуть не лише у системі професійно значущих знань, але й сформованості особистісних установок. Серед можливих негативних наслідків, за умови цього типу організації навчання, перше місце у висловлюваннях студентів посіла ідея «руйнування професійної мотивації». Вона була позначена третиною опитаних здобувачів вищої освіти $(27,5 \%)$, водночас прогалини у системі знань і умінь відзначив лише кожний шостий учасник опитування (17,5\%). Можна погодитися 3 правомірністю висновків студентів. Входження людини у інші кола трудової діяльності на етапі первинного формування елементів професійної ідентичності та несформованої мотивації може викликати не лише гальмування цього процесу, а й протидіяти йому.

Як уже зазначалося, однією із можливих причин інтенсифікації трудової активності студентства може виступати скрутне становище родини, у якій вони проживають. Проте, як показало обстеження, більшість респондентів не визнали такого статусу своїх родин ні у плані матеріального, ні фінансового забезпечення. На думку студентів, їх родини мають середній рівень економічного благополуччя (у межах 5-6 балів із 10-ти можливих). Крім того, частина вибірки визнала ще більш сприятливий економічний статус своїх родин. На питання про те, чи мають батьки можливість утримувати їх впродовж усього навчання у закладі вищої освіти, всі студенти дали ствердну відповідь. При цьому, лише 5\% оцінили 
можливості батьків на 3-4 бали. Значна частина (47,5\%) підняли цей показник до 7-10 балів iз 10 можливих. Отже, загроза економічного неблагополуччя родини у нашому випадку не може розглядатися як одна із мотиваційних спонук працевлаштування студентів. Можна припустити, що потенційною причиною є небажання батьків утримувати своїх дорослих дітей. Перевірка цієї ідеї також не отримала підтвердження. Лише незначна частина вибірки (12,5\%) вказала на середній рівень готовності батьків (у межах 5 балів із 10 можливих) нести матеріальні затрати по утриманню своїх дітей. В переважної більшості вибірки $(77,5 \%)$ цей показник знаходиться на найвищому рівні. Тобто батьки не лише мають економічну можливість, але й демонструють психологічну готовність підтримувати своїх дітей у період навчання у вищій школі. Студенти це відчувають, усвідомлюють і відповідно декларують. Цікавим є той факт, що працевлаштування молоді викликає досить амбівалентні почуття у їхніх батьків. Незважаючи на те, що більшість батьків (62,5\%), на думку їхніх дітей, мають приємні переживання (зокрема радість, гордість), все ж у третини учасників опитування основними типами емоційного реагування батьків є переживання емоційного дискомфорту, гіркоти, смутку, невдоволення. Батькам подобається, що їхні діти демонструють особистісну зрілість і самостійність, проте розуміння негативних наслідків, які можуть виникати у навчанні, чи у подальшій професійній діяльності та здоров’ї їхніх дітей викликають занепокоєння, яке домінує над приємними переживаннями. Варто зазначити, що лише окремі батьки (7,5\%) стали ініціаторами працевлаштування студентів. В 92,5\% випадків це самостійний вибір студента, який був прийнятий більшістю батьків (75\%), незважаючи на переживання певного внутрішньоособистісного конфлікту.

Певне світло на вивчення природи прагнень студентів до поєднання навчання у виші 3 трудовою діяльністю проливає і аналіз спрямувань фінансових надходжень, що з'являються у молодої людини за таких умов життєдіяльності. Вивчення процесу і результату оцінювання молоддю цілей заробітку грошей, дозволяє стверджувати, що центральне місце у системі їх використання належить ідеї «задоволення власних життєво важливих цілей». Така позиція була задекларована половиною учасників опитування (52,5\% вибірки). Другу рангову позицію зайняли ідеї «витрачання грошей для саморозвитку», тобто мати фінансову можливість отримати освіту, купувати книги, відвідувати театр, музеї. Ці позиції обрали $17,5 \%$ респондентів. Така ж кількість респондентів виокремили ідею «для допомоги близьким» (17,5\%). Тобто, прагнучи працювати, студенти перш за все міркують над можливістю утримувати себе. Отже, не ситуативні, а диспозиційні змінні є причиною уваги студентів до працевлаштування у період навчання в університеті.

Звернемо увагу на ті мотиваційні підстави, які змушують студентів робити крок до поєднання освітньої й трудової діяльності у період навчання у виші. Факторний аналіз мотиваційних спонук економічної поведінки молоді дозволив виокремити три фактори: фактор незалежності (Н), фактор трудового досвіду (ТД) і фактор зовнішньої стимуляції (3С). Як видно з табл. 1, до першої факторної групи $(\mathrm{H})$ увійшли чотири мотиви, а саме: мотив самоутвердження $(0,814)$; усвідомлення власної дорослості $(0,802)$; прагнення до економічної незалежності $(0,796)$ та мотив матеріальних труднощів сім'ї $(-0,787)$. Прямий вплив на прийняття рішень про працевлаштування виконують диспозиційні чинники, що підтверджує розвиток процесів автономізації молодої людини. До першого фактора увійшов і мотив матеріальних труднощів сім’ї, хоча із протилежним значенням. Це засвідчує, що у формуванні мотиваційних установок, не матеріальні потреби сім’ї ідентифікуються молодою 
людиною як центральна спонука їх трудової активації, а саме вироблення власних позицій, особистісне прагнення демонструвати свою зрілість.

Таблиия 1

Результати факторного аналізу мотивів працевлаштування студентів

\begin{tabular}{|c|c|c|c|}
\hline \multirow{2}{*}{$\begin{array}{c}\text { Суб'сктивно значущі мотиви } \\
\text { працевлаштування }\end{array}$} & \multicolumn{3}{|c|}{ Фактори } \\
\hline & $\begin{array}{l}\text { фактор } \\
\text { незалежності } \\
\text { (Н) }\end{array}$ & $\begin{array}{l}\text { фактори } \\
\text { трудового } \\
\text { досвіду (ТД) }\end{array}$ & $\begin{array}{l}\text { фактор } \\
\text { зовнішньої } \\
\text { стимуляції (3С) }\end{array}$ \\
\hline самоутвердження & 0,814 & & \\
\hline усвідомлення власної дорослості & 0,802 & & \\
\hline $\begin{array}{lll}\text { прагнення } & \text { до } & \text { економічної } \\
\text { незалежності } & & \end{array}$ & 0,796 & & \\
\hline $\begin{array}{lll}\text { мотив } & \text { матеріальних } & \text { труднощів } \\
\text { сім’ї } & & \end{array}$ & $-0,787$. & 0,329 & \\
\hline мотив заробітку & & $-0,840$ & $-0,269$ \\
\hline $\begin{array}{l}\text { поява цілей, що вимагають } \\
\text { грошового забезпечення }\end{array}$ & -0306 & $-0,657$ & $-0,485$ \\
\hline мотив набуття професійних умінь & & 0,646 & $-0,327$ \\
\hline мотив набуття трудового досвіду & $-0,314$ & 0,531 & \\
\hline мотив моди & $-0,204$ & & 0,819 \\
\hline зразки поведінки друзів & 0,258 & & 0,796 \\
\hline
\end{tabular}

Другий фактор (ТД) утворили чотири спонуки: мотив заробітку $(-0,840)$; мотив виникнення нових цілей, пов'язаних із грошовими витратами $(-0,657)$; мотив набуття професійних умінь $(0,646)$ і мотив трудового досвіду $(0,531)$. Об'єднавшись у загальний комплекс, два останні мотиватори (мотив трудового досвіду та набуття професійних умінь) демонструють наявність обернено кореляційних зв'язків зі спонуками фінансовоматеріального спрямування. На нашу думку, ця закономірність зумовлена розбіжністю у напрямках трудової самореалізації студентів та їх професійної підготовки у ЗВО. Заробіток грошей на молодших курсах не пов'язаний з набуттям студентами професійних умінь та відповідного професійного досвіду. До третьої факторної групи увійшли мотиви моди $(0,819)$ і мотиви зразків поведінки друзів $(0,796)$. Результати засвідчують, що фінансова складова трудової діяльності не сприймається молоддю як основна спонукальна сила організації їхньої життєдіяльності та самореалізації.

Зіставивши отримані результати із ідеями використання зароблених грошей можна стверджувати, що у процесі прийняття рішення про працевлаштування превалює все ж мотив особистісного спрямування. Фактично більшість респондентів $(72,5 \%)$ відзначили, що гроші необхідні їм для задоволення власних життєво важливих потреб (52,5\%), саморозвитку $(17,5 \%)$ і відпочинку (2,5\%). Лише третина респондентів поставила на перше місце допомогу рідним чи іншим значимим людям. Трудова мотивація позначається і на визначенні цілей, які прагне реалізувати молода людина в процесі трудової діяльності. Як засвідчило опитування, 42,5\% респондентів пов'язують свою трудову діяльність із можливістю отримання грошей, натомість стратегія самоутвердження виокремлюється лише незначною 
кількістю учасників (20\%). Ще рідше вони пов'язують свою діяльність із набуттям професійних умінь (15\%) чи загалом трудового досвіду (5\%). Ці показники ще раз засвідчують, що трудова діяльність студента далека від лінії його професійного навчання.

Як відомо, важливим показником світосприйняття особистості є переживання нею свого економічного благополуччя. Можна припустити, що саме ці переживання виконують стимулюючу функцію для започаткування студентами стратегії заробітку грошей. Згідно ідей В. Хащенка (Хащенко, 2011), конструкт економічного благополуччя особистості об'єднує п’ять основних компонентів: економічний оптимізм, відчуття суб'єктивної адекватності доходів і витрат; суб'єктивна оцінка матеріальних статків сім’ї; економічні хвилювання і тривоги суб'єкта. Так, індекс економічного оптимізму і впевненості у завтрашньому дні респондентів підтверджує наявність середніх рівнів задоволеності благополуччям життєвої ситуації. Більшість зазначають, що в останній період відбулися позитивні зміни у їхньому добробуті та матеріальних статках родин. Оцінюючи свої потенційні можливості, вони декларують оптимістичні налаштування. Водночас оцінка сприятливості економічної ситуації в країні менш оптимістична, що, відповідно, зумовлює і зниження загального індексу економічного оптимізму. Загалом за цим показником виявлено, що половина респондентів декларує високий (20\%) чи середній $(32,5 \%)$ рівень (див. табл. 2).

Таблиия 2

Розподіл вибірки за рівнями суб'єктивного сприйняття економічного благополуччя

\begin{tabular}{|l|c|c|c|c|c|c|}
\hline \multirow{2}{*}{ Рівні } & \multicolumn{5}{|c|}{$\begin{array}{l}\text { Кількісні показники наповнюваності підгруп різного рівня } \\
\text { економічного благополучч за основними шкалами (у\%) }\end{array}$} \\
\cline { 2 - 7 } & $\begin{array}{l}\text { економ. } \\
\text { оптимізм }\end{array}$ & $\begin{array}{l}\text { адекватність } \\
\text { доходів } \\
\text { запитам }\end{array}$ & $\begin{array}{l}\text { статок } \\
\text { сім’ї }\end{array}$ & $\begin{array}{l}\text { фінансова } \\
\text { депривація }\end{array}$ & $\begin{array}{l}\text { економічна } \\
\text { тривога }\end{array}$ & $\begin{array}{l}\text { загальне } \\
\text { економічне } \\
\text { благополуччя }\end{array}$ \\
\hline високий & 20 & 7,5 & 17,5 & 15 & 7,5 & 15 \\
\hline середній & 32,5 & 57,5 & 40 & 47,5 & 40 & 45 \\
\hline $\begin{array}{l}\text { нижче } \\
\text { середнього }\end{array}$ & 40 & 22,5 & 35 & 27,5 & 50 & 32,5 \\
\hline низький & 7,5 & 12,5 & 7,5 & 10 & 2,5 & 7,5 \\
\hline
\end{tabular}

В 40\% опитаних діагностовано рівень економічного оптимізму нижче середнього. Низький рівень зафіксовано лише у окремих учасників опитування $(7,5 \%)$. В питаннях суб'єктивного відчуття збалансованості доходів сім'ї та їі потреб, помічено, що студенти обирають для оцінки цієї характеристики переважно показники середнього рівня. При цьому найвищі бали отримала позиція можливостей забезпечити потребу у власній безпеці $(M=4,0$; $S D=0,84)$, найнижчі - у задоволенні потреби досягнення матеріального благополуччя $(M=3,2$; $\mathrm{SD}=0,62)$. За шкалою фінансової депривації також були отримані показники середнього рівня. Індекс ступеня достатку-нестачі фінансових засобів, за результатами дослідження, знаходиться у межах 18,5 бали (при нормі для жіночої вибірки 17,43, 3 розміром стандартного відхилення 3,48). Отже, можна констатувати, що навіть незначні заробітки дозволяють молоді відчувати певну економічну захищеність. Як наслідок, лише незначна частина учасників опитування $(7,5 \%)$ декларують низький рівень емоційного благополуччя за шкалою фінансової депривації. 
Показовим є також той факт, що неможливість покращити своє фінансове становище не сприймається молоддю у контексті безвихідності й розпачу. Потрапляючи у ситуації фінансових невдач, половина опитаних (50\%) використовує стратегію уникання, витіснення проблеми, п’ята частина вибірки $(22,5 \%)$ вказує на активацію стратегії пошуку шляхів вирішення проблеми. I лише незначна частина студентів $(7,5 \%)$ зазначає про виникнення пасивно-депресивних станів сприйняття ситуації. Отже, можна стверджувати, що молодіжний оптимізм сприяє формуванню адекватного реагування на життєві труднощі, зумовлені порушенням економічного благополуччя.

Досить цікавим показником життєдіяльності студентів є наявність чи відсутність переживань ними економічного стресу. Згідно зі стереотипами сприйняття студентського періоду життя як епохи безгрошів'я та економічної залежності, можна припустити, що молодь буде вказувати на переживання гострої економічної стурбованості. За результатами опитування за методикою Хащенка, індекс економічної тривоги і стурбованості (IET) в респондентів виявився нижче середніх значень (18,98 балів, при середній нормі показників 20,47 балів для жіночої вибірки). Загалом, визнаючи певну нестачі грошей і середній ступінь занепокоєння своїм матеріальним становищем, зумовленим економічною ситуацією в країні, учасники опитування показали досить високу міру оптимізму щодо свого економічного майбутнього та невисоку інтенсивність сформованості бажань мати гроші $(M=2,2 ; S D=1,0)$ й відчувати їх значущість у сьогоденні. Відповідаючи на питання: «Наскільки значущими для Вас $\epsilon$ гроші на цей час?», більшість опитаних обрали позицію «низький ступінь значущості» $(M=2,4 ; S D=0,5)$. Інтегральний індекс суб' єктивного економічного благополуччя склав 84,8 (при середній нормі 78,8), що свідчить про достатньо комфортне самопочуття наших респондентів у сфері матеріально-фінансових реалій власної життєдіяльності.

Наступним кроком було з'ясування впливу фактору суб'єктивного економічного благополуччя на значущість різних мотивів працевлаштування за допомогою тесту Крускала-Уолеса. Результати засвідчують, що ставлення студентів до різних мотивів є доволі схожим, незалежно від їх рівня суб'єктивного економічного благополуччя. Лише показники деяких мотивів працевлаштування вказують на певні відмінності в оцінюванні студентами їх значущості. Зокрема, респонденти, віднесені до різних груп суб'єктивного благополуччя, порізному оцінюють мотив матеріальних труднощів сім’ї $y^{2}=12,74$ (p $\left.\leq 0,01\right)$, мотив набуття професійних умінь $y^{2}=10,29(\mathrm{p} \leq 0,01)$ та трудового досвіду $y^{2}=18,45(\mathrm{p} \leq 0,01)$. Студенти, які задекларували високий рівень благополуччя, меншою мірою опікуються матеріальним становищем сім’ї $\left(M_{1}=1,67 ; S D=0,77\right)$, набуттям трудового досвіду $\left(M_{2}=2,5 ; S D=0,52\right)$ та професійних вмінь $\left(M_{3}=3,0 ; S D=0,85\right)$, порівняно з групою з низьким рівнем благополуччя (відповідно $M_{1}=2,75 ; \mathrm{SD}=1.58 ; M_{2}=4,0 ; \mathrm{SD}=0,46 ; M_{3}=3,25 ; \mathrm{SD}=0,75$ ). Потрібно також відзначити, що за значущістю показника матеріальних проблем сім'ї найбільша розбіжність в оцінках спостерігається не між групами високого і низького рівнів суб'єктивного економічного благополуччя, а між групами високого і середнього рівнів, а також середнього і низького. На нашу думку, це пов'язано з певною егоцентричною спрямованістю молоді в цьому віці. Суб'єктивне переживання економічного неблагополуччя і повна задоволеність своїм економічним станом провокують надання меншої уваги проблемам батьківської сім'ї, та вищу зосередженість на власних інтересах. Подібна тенденція спостерігається також при оцінюванні цілей, на які студенти планують витрачати зароблені кошти. При оцінюванні важливості допомоги близьким людям найбільші розбіжності фіксуються між групами 3 
високим $\left(M_{1}=2,50 ; S D_{1}=0,52\right)$ і середнім рівнем суб'єктивного благополуччя $\left(M_{2}=3,75\right.$; $\left.S D_{2}=1,03\right)$.

Відсутність надмірної акцентуації молоді на грошах підтверджується і результатами методики «Іерархія потреб» (модиф. І. Акіндінової). Серед п’яти груп мотиваційних спонук, запропонованих для аналізу (потреба у самовираженні, в безпеці, у визнанні, матеріальні потреби, соціальні потреби), домінуючі позиції отримала перша група спонук. Вона об'єднує ідеї, що позначають спрямування особистості на самореалізацію, розвиток власних сил $\mathrm{i}$ здібностей, прагнення до нового й невідомого. За цією шкалою середній показник по вибірці склав 23 бали $(S D=6,26)$ (див. рис. 1). Домінування прагнення респондентів до самореалізації відповідає нормативним характеристикам юнацького віку.

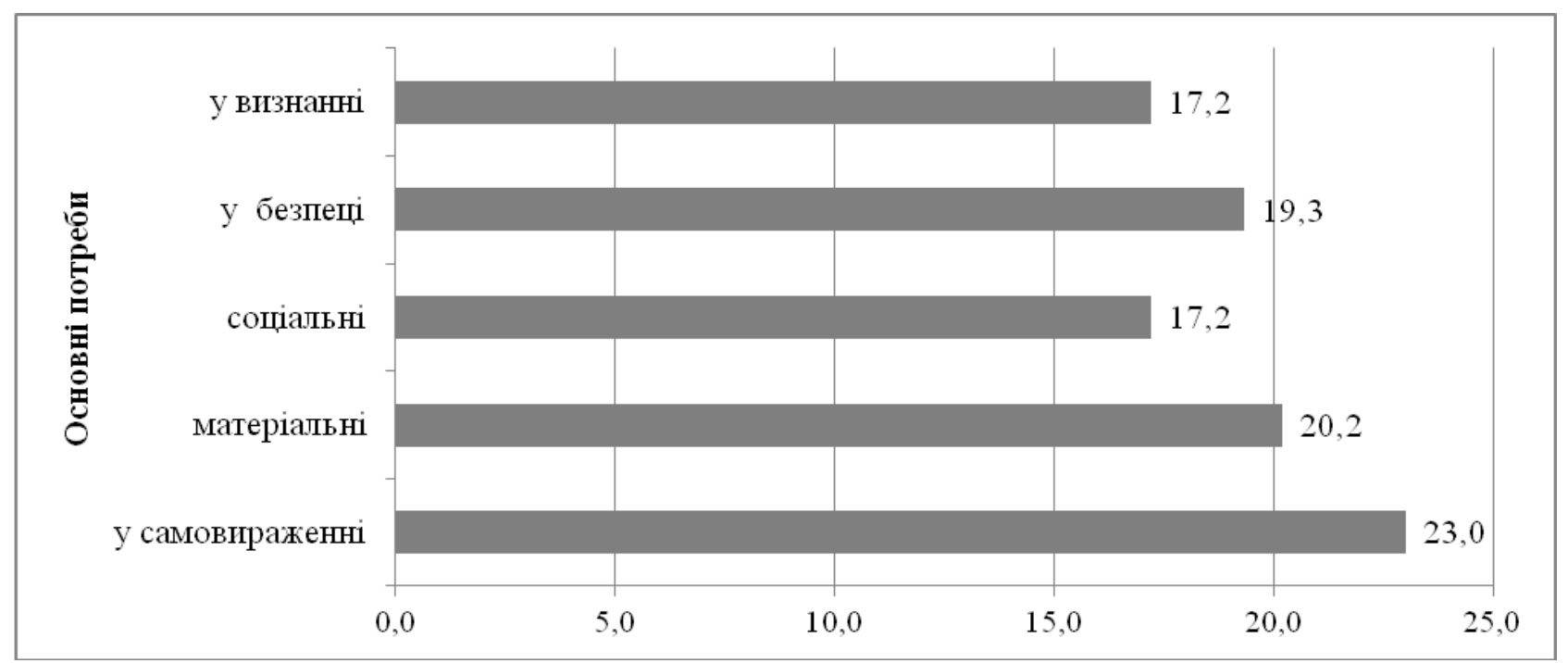

Рис. 1. Середні показники оцінювання значущості основних потреб

Група потреб економічного спрямування посіла друге місце $(M=20,2 ; S D=5,29)$. Отримані результати демонструють, що дані потреби знаходяться за межами зони задоволення. Водночас вони не перевищили середні значення зони часткового задоволення, межі якої знаходяться у діапазоні 15-28 одиниць, а отже, не засвідчують гостроти суб'єктивного сприйняття цієї потреби. Аналізуючи зв'язок між оцінюванням значущості основних потреб і суб'єктивним економічним благополуччям, потрібно зазначити, що студенти практично одностайні в своїх оцінках щодо потреби у безпеці та матеріальних потреб. Вищі потреби (у комунікації, визнанні та самовираженні) по-різному оцінюються респондентами в залежності від їх задоволеності своїм економічним станом (див. табл. 3).

Таблиия 3

Показники відмінностей у оцінюванні значущості основних потреб респондентами 3 різним рівнем суб'єктивного матеріального благополуччя (за тестом Крускала-Уолеса)

\begin{tabular}{|c|c|c|c|c|c|}
\hline $\mathbf{4}^{\mathbf{2}}$ & $\begin{array}{c}\text { Матеріальні } \\
\text { потреби } \\
\text { df }\end{array}$ & $\begin{array}{c}\text { Потреба у } \\
\text { безпеці } \\
5,724\end{array}$ & $\begin{array}{c}\text { Соціальні } \\
\text { потреби } \\
16,441\end{array}$ & $\begin{array}{c}\text { Потреба у } \\
\text { повазі } \\
15,503\end{array}$ & $\begin{array}{c}\text { Потреба у } \\
\text { самовираженні } \\
15,253\end{array}$ \\
\hline Sig. & 3 & 3 & 3 & 3 & 3 \\
\hline
\end{tabular}


Для більш повного уявлення про ставлення студентської молоді до грошей, ми провели обстеження за методикою «Опитувальник вимірювання монетарних аттитюдів» (Klotz та ін., 2011), яка містить 4 шкали: «уникання грошей», «гроші як статус», «поклоніння грошам», «уважне ставлення до грошей». Зокрема у шкалі «уникання грошей» можна виокремити дві центральні ідеї - визнання-невизнання респондентом можливості бути хорошою людиною, попри наявність грошей («Хороших людей не повинні цікавити гроші»; «Важко бути багатим, але хорошим одночасно») і осуд власних прав чи можливостей мати високі статки («Я не заслуговую на те, щоб мати гроші»). Як засвідчують результати, міркування більшості респондентів знаходяться у межах статистичної норми. Процес їхнього дорослішання відбувається в умовах функціонування ринкової економіки, тому вони не ставляться з осудом до грошей та можливостей їх надбання й володіння. Все ж, ідея «Гроші псують людей» отримала достатньо високу міру визнання (4 бали із 6 можливих), що не дивно в умовах сьогоденних реалій.

За шкалою «гроші як цінність» показники наших респондентів також знаходяться у межах норми. Із можливих 60 балів, визнання ідей «Гроші - ось сенс життя», «Успіх людей залежить лише від грошей» та інших п'яти тверджень цієї шкали, отримало лише 18,44 бала. Відповідно, більшість учасників $(68,3 \%)$ за цим критерієм віднесені нами до середнього рівня сформованості аттитюдної установки (див. табл 4).

Таблиия 4

Розподіл учасників опитування за рівнем визнання монетарних аттитюдов

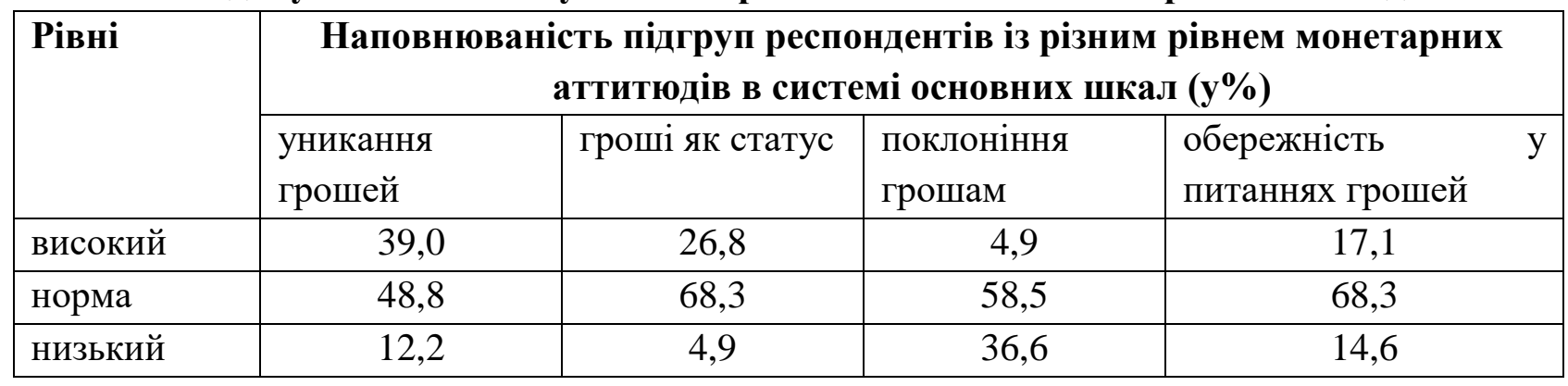

Для нашого дослідження досить значущими $є$ установки студентства щодо поклоніння грошам, сприйняття їх як шляху і засобу реалізації особистісних проблем. В методиці ця шкала презентована такими твердженнями: «Гроші - це влада», «Гроші купують свободу», «Більша кількість грошей зробить тебе щасливою» і т.ін. За жодною із означених позицій середня статистична норма респондентами не була перевищена. До того ж, саме за цією шкалою переважна кількість респондентів $(95,1 \%)$ віднесена нами до низького $(36,6 \%)$ чи середнього $(58,5 \%)$ рівнів визнання. Отже, отримані результати дозволяють прогнозувати, що в респондентів не повинні спостерігатися такі розлади у сфері фінансової поведінки, як надмірний шопоголізм чи схильність до азартності у використанні грошей.

Серед монетарних аттитюдів, які простежувалися нами у процесі дослідження, були і ідеї обережності молоді у обговоренні питань, пов'язаних із наявністю та використанням грошей. Найбільш обережно ставляться студенти до ідей обговорення 3 іншими своїх заробітків чи розпитувань інших про ці аспекти життя. Загалом високий ступінь визнання атитюду «обережність у питаннях грошей» отримано в 17,1\% респондентів. Решта, у своїй переважній більшості (68,7\%), визнають наявність цього установочного конструкту на рівні 
середньо статистичних показників. Отже, це свідчить про достатньо зріле ставлення молоді до грошей та відповідність їх установок сучасним реаліям життя.

Проведений кореляційний аналіз дозволяє стверджувати, що монетарні установки перебувають у зв'язку з показниками загального суб'єктивного економічного благополуччя та його окремими шкалами. Так, уявлення про гроші як статус значною мірою пов'язані 3 фінансовою депривованістю $(\mathrm{r}=-0,56 ; \mathrm{p} \leq 0,001)$ і меншою мірою 3 економічною тривожністю $(\mathrm{r}=-0,27 ; \mathrm{p} \leq 0,05)$, а також мають помірний обернений зв'язок із загальним показником суб'єктивного благополуччя $(\mathrm{r}=-0,34 ; \mathrm{p} \leq 0,05)$. Тобто задоволеність своїм економічним станом дозволяє студентам більш конструктивно вибудовувати взаємини з іншими людьми, оцінюючи їх не лише за ознаками матеріального статусу, а також обирати раціональні стратегії поведінки зі своїми фінансами. Як вже зазначалося, молодь обережніше ставиться до обговорення фінансових питань, і ця тенденція демонструє позитивний зв'язок із економічним оптимізмом $(\mathrm{r}=0,35 ; \mathrm{p} \leq 0,01)$. На практиці це виявляється в тому, що висока задоволеність своїм фінансовим станом та впевненість у ньому в подальшому узгоджується 3 принципом «гроші люблять тишу», водночас тривога за свої фінансові перспективи актуалізує прагнення порівнювати себе з іншими та обговорювати тему грошей.

\section{Висновки}

Проведене дослідження дає підстави стверджувати, що основними детермінантами пошуку студентами роботи під час навчання у ЗВО є не стільки об'єктивні економічні умови їх життя, скільки внутрішнє прагнення до унезалежнення від батьківської сім'ї, до встановлення особистісної автономії, зокрема й фінансової. Домінуючі позиції потреби у самовираженні та високі показники мотивів усвідомлення власної дорослості, прагнення до економічної незалежності, тісні зв'язки між ними (що дало змогу об'єднати їх в єдиний фактор економічної незалежності) у поєднанні з високими показниками суб'єктивного економічного благополуччя є підтвердженням цієї гіпотези. Студенти також підтверджують ідею, що їх батьки мають як фінансові можливості, так і психологічну готовність надавати їм підтримку протягом всього терміну навчання у ЗВО. Більше того, батьки демонструють амбівалентні або, навіть, негативні емоційні реакції на повідомлення дітей про працевлаштування, оскільки розуміють, що це може негативно вплинути на якість навчання.

3 одного боку, здобуття певної фінансової незалежності, зміна ставлення до грошей, формування більш зваженої та конструктивної стратегії в поведінці з ними є природними складовими процесу дорослішання та індивідуації. 3 іншого боку, ця тенденція може мати цілий ряд негативних наслідків, особливо вона стосується формування професійних компетенцій майбутніх фахівців. Незважаючи на те, що більшість студентів позначають 4-й рік навчання, як найоптимальніший час для початку трудової діяльності, $90 \%$ з них до 3-го курсу вже мають досвід поєднання навчання та роботи. Основною проблемою, 3 якою студенти зустрічаються при цьому, є те, що робота, зазвичай, не відповідає обраному фаху. До того ж, формула «навчатись, працюючи» часто перетворюється на «працювати, навчаючись», що не лише не сприяє формування професійних умінь, а, навпаки, створює перешкоди на цьому шляху, інколи руйнуючи професійну та навчальну мотивацію загалом. Потрібно зазначити, що відповіді студентів засвідчують, що вони чітко усвідомлюють ці ризики, проте бажання відчувати себе «дорослими» та «незалежними» все ж переважає. На широкому соціальному рівні подібна тенденція зумовлює зниження якості вищої освіти 
загалом, що, в свою чергу, призводить до скептичного ставлення та недовіри роботодавців до дипломів українських вишів.

Підсумовуючи окреслену проблему, потрібно зазначити, що потенційним напрямком наукового пошуку може бути наявність гендерних та демографічних відмінностей у ставленні молоді до поєднання навчання і роботи. Крім того, за межами дослідження залишилися вікові аспекти формування зазначених атитюдів: чи відрізняються думки студентів перших останніх курсів, а також випускників щодо доцільності такого поєднання.

\section{Література}

1. Акиндинова, И.А. (2000). Особенности самоактуализации личности в профессиях различного уровня социального престижа. (Дис. канд. психол. наук). Санкт-Петербург.

2. Дзукаева, В.П., \& Садовникова, Т.Ю. (2014). Адаптация опросника PSI (Psychological Separation Inventory) на российской выборке. Семейная психология и семейная терапія, 1, $3-15$.

3. Дзукаева, В.П. (2016). Культурно-специфические и семейные факторы сепарачии от родительской семьи в юношеском возрасте. (Дис. канд. психол. наук). Москва. Режим доступа: http://www.psy.msu.ru/science/autoref/dzukaeva/dzukaeva_diss.pdf

4. Дитюк, А.А. (2015). Психологическая сепарация как феномен межличностных отношений: к проблеме определения понятия. Вестник ЮУрГУ. Серия «Психология», $8(3), 98-102$.

5. Карамушка, Л.М., \& Ходакевич, О.Г. (2017). Психологічні особливості ставлення студентської молоді до грошей. (Монографія). Київ : КНЕУ.

6. Ковальчук, А.Л. (2013). Зв'язок я-концепції із сепарацією від батьків у юнацькому віці. Науковий вісник Львівського державного університету внутрішніх справ. серія психологічна, 1, 65-73. Режим доступу: http://nbuv.gov.ua/UJRN/Nvldu_2013_1_9.

7. Литвинова, А.В. (2020). Психологическая сепарация от родителей как условие развития целеполагания студентов. Психолого-педагогические исследования, 12(1), 59-71. doi:10.17759/psyedu.2020120105.

8. Літвінова, О.В. (2018). Проблема впливу батьків на процес психічної сепарації в юнацькому віці. Науковий вісник Херсонського державного університету, 2(3), 144-150.

9. Маленова, А.Ю., \& Потапова, Ю.В. (2013). Феномен сепарации: определение проблемного поля исследования. Вестник Омского университета. Серия «Психология», 2, 41-48.

10. Петренко, Т.В., \& Сысоева, Л.В. (2016). Возрастные этапы процесса сепарации от родителей. Акмеология и психология развития, 4(60), 180-184.

11. Хащенко, В.А. (2011). Субъективное экономическое благополучие как предиктор субъективного качества жизни. Теоретическая и экспериментальная психология, 4(4), $13-29$.

12. Широка, А.О. (2013). Спроба інтеграції концепції сепарації-індивідуації у вітчизняну психологію. Проблеми сучасної психологї: Збірник наукових пращь Кам'янецьПодільського національного університету імені Івана Огієнка, 21, 770-782.

13. Aslan, S, \& Gelbal, S. (2016). Separation-1ndividuation of late adolescents: A longitudinal study. Educational Research and Reviews, 11, 1-15. doi 10.5897/ERR2015.2570.

14. Hoffman, J.A. (1984). Psychological separation of late adolescents from their parents. Journal of Counseling Psychology, 31, 170-178.

15. Geuzaine, C., Debry, M., \& Liesens, V. (2000). Separation from Parents in Late Adolescence: The Same for Boys and Girls? Journal of Youth and Adolescence, 29, 79-91. doi 10.1023/A:1005173205791.

16. Klontz, B., Britt, S.L., Mentzer, J., \& Klontz, T. (2011). Money Beliefs and Financial Behaviors: Development of the Klontz Money Script Inventory. Journal of Financial Therapy, 2(1) 1-22. https://doi.org/10.4148/jft.v2i1.451 


\section{References}

1. Akindinova, I.A. (2000). Osobennosti samoaktualizacii lichnosti v professijah razlichnogo urovnja social'nogo prestizha [Features of individual's self-actualization in professions with different levels of social prestige]. Candidate's thesis. Sankt-Peterburg [in Russian].

2. Dzukaeva, V.P., \& Sadovnikova, T.Ju. (2014). Adaptacija oprosnika PSI (Psychological Separation Inventory) na rossijskoj vyborke. [Adaptation of Psychological Separation Inventory on a Russian sample]. Semejnaja psihologija i semejnaja terapija - Family psychology \& family therapy, 1, 3-15. [in Russian ].

3. Dzukaeva, V.P. (2016). Kul'turno-specificheskie i semejnye faktory separacii ot roditel'skoj sem'i v junosheskom vozdaste [Cultural and family factors of separation from the parental family in adolescence]. Candidate's thesis. Moscow. Retrieved from http://www.psy.msu.ru/ science/autoref/dzukaeva/dzukaeva_diss.pdf [in Russian].

4. Ditjuk, A.A. (2015). Psihologicheskaja separacija kak fenomen mezhlichnostnyh otnoshenij: k probleme opredelenija ponjatija. [Psychological separation as a phenomenon of interpersonal relations: to the problem of concept definition]. Vestnyk YuUrHU. Seryia "Psykholohyia" Bulletin of the South Ural State University. Series "Psychology", 8(3), 98-102 [in Russian].

5. Karamushka, L.M., \& Khodakevych, O.H. (2017). Psykholohichni osoblyvosti stavlennia studentskoi molodi do hroshei [Psychological features of students' attitudes towards money:Monografy]. Kyiv : KNEU [in Ukrainian].

6. Kovalchuk, A.L. (2013). Zviazok ya-kontseptsii iz separatsiieiu vid batkiv u yunatskomu vitsi. [Connection between ego-concept and separation from parents in adolescence]. Naukovyi visnyk Lvivskoho derzhavnoho universytetu vnutrishnikh sprav. Seriia psykholohichna - Bulletin of the Lviv State University of Internal Affairs. Psychological series, 1, 65-73. Retrieved from http://nbuv.gov.ua/UJRN/Nvldu_2013_1_9 [in Ukrainian].

7. Litvinova, A.V. (2020). Psihologicheskaja separacija ot roditelej kak uslovie razvitija celepolaganija studentov [Psychological separation from parents as a condition for the development of students' goal-setting]. Psihologo-pedagogicheskie issledovanija Psychological and Educational Studies, 12(1), 59-71. doi:10.17759/psyedu.2020120105 [in Russian].

8. Litvinova, O.V. (2018). Problema vplyvu batkiv na protses psykhichnoi separatsii v yunatskomu vitsi [The problem of parents' influence on the process of psychological separation in adolescence ]. Naukovyi visnyk Khersonskoho derzhavnoho universytetu - Scientific Bulletin of Kherson State University. Series "Psychological Sciences", 2(3), 144-150 [ in Ukrainian].

9. Malenova, A.Ju., \& Potapova, Ju.V. (2013). Fenomen separacii: opredelenie problemnogo polja issledovanija [The separation phenomenon: finding of the problem field of research]. Vestnik Omskogo universiteta. Serija "Psihologija" - Bulletin of Omsk University. Series "Psychology", 2, 41-48 [in Russian].

10. Petrenko, T.V., \& Sysoeva, L.V. (2016). Vozrastnye jetapy processa separacii ot roditelej [Age stages of the process of separation from parents]. Akmeologija $i$ psihologija razvitija Acmeology and Developmental Psychology, 4(60), 180-184 [in Russian].

11. Hashhenko, V.A. (2011). Subektivnoe jekonomicheskoe blagopoluchie kak prediktor sub\#ektivnogo kachestva zhizni. [Subjective economic well-being as a predictor of subjective quality of life]. Teoreticheskaja $i$ jeksperimental'naja psihologija - Theoretical and Experimental Psychology, 4(4), 13-29 [in Russian].

12. Shyroka, A.O. (2013). Sproba intehratsii kontseptsii separatsii-indyviduatsii u vitchyznianu psykholohiiu. [An attempt to integrate the concept of separation-individuation in domestic psychology]. Problemy suchasnoi psykholohii: Zbirnyk naukovykh prats Kamianets-Podilskoho natsionalnoho universytetu imeni Ivana Ohiienka - Problems of Modern Psychology: Collection of research papers of Kamianets-Podilskyi National Ivan Ohiienko University, 21, 770-782 [in Ukrainian].

13. Aslan, S, \& Gelbal, S. (2016). Separation-1ndividuation of late adolescents: A longitudinal study. Educational Research and Reviews, 11, 1-15. doi 10.5897/ERR2015.2570.

14. Hoffman, J.A. (1984). Psychological separation of late adolescents from their parents. Journal of Counseling Psychology, 31, 170-178. 
15. Geuzaine, C., Debry, M., \& Liesens, V. (2000). Separation from Parents in Late Adolescence: The Same for Boys and Girls? Journal of Youth and Adolescence, 29, 79-91. doi 10.1023/A:1005173205791.

16. Klontz, B., Britt, S.L., Mentzer, J., \& Klontz, T. (2011). Money Beliefs and Financial Behaviors: Development of the Klontz Money Script Inventory. Journal of Financial Therapy, 2(1) 1-22. https://doi.org/10.4148/jft.v2i1.451

\author{
INTEGRATION OF EDUCATIONAL AND EMPLOYMENT ACTIVITIES \\ AS REALISATION OF YOUTH ASPIRATION TO FINANCIAL SEPARATION \\ Nataliia Korchakova \\ Doctor of Sciences in Psychology, Associate professor, \\ Professor of the Department of Developmental and Pedagogical Psychology \\ Rivne State University of the Humanities \\ 12, S. Bandery St., Rivne, Ukraine, 033000 \\ nataliia.korchakova@ rshu.edu.ua, http://orcid.org/0000-0003-1164-3370
}

\begin{abstract}
The current tendency of students to combine education with work can have both positive and negative consequences: maturity and economic autonomy on the one hand, and the loss of system and consistency of professional knowledge acquisition on the other hand. It might lead to a decrease in the quality of professional competencies and, finally, to devaluation of the essence of higher education in general. It is worth noting that in this case we are not talking about the implementation of the principle of dual education, as most students' employments are not related to the direction of their professional course, and therefore do not provide improving their professional knowledge or skills. The purpose of the article is to analyze the motivational aspect of students' intentions to gain economic independence from the parental family by combining higher education with employment. 80 third-year students $(M=19.7$ years old) participated in the study. The results obtained confirmed the suggestion that the main motivational basis to make decision about the employment was not the need to solve the financial difficulties but an aspiration to achieve the personal autonomy and independence. The study proved the ambivalent nature of the process, as being temporarily or parttime employees, the students could not fulfill all their needs and continued to rely on financial support of their parents. Only $9.8 \%$ of respondents confirmed their complete financial independence from the family or even the ability to support their parents. At the same time, all the respondents admitted the perception of the negative influence of their absence from study on the level of their professional skills. The factor analysis of students' motivation has resulted in distinguishing 3 main factors: "independence" (formed with motives of self-affirmation, awareness of maturity, commitment to financial autonomy and family's financial difficulties); "experience" (motives of gaining professional experience, skills and earning for living); "external influence" (motives of new social trends and peers' role models). Comparing the motives of financial separation with the desirable goals of spending money, we made a conclusion about a dominant role of personal and sometimes even egoistic needs in making decision to search for a job (money for living, for selfdevelopment and entertainment).
\end{abstract}

Keywords: psychological separation, financial separation, subjective financial well-being, money beliefs, youth, students. 